\title{
Analysis of anti-racism, equity, inclusion and social justice initiatives in library and information science literature
}

\author{
Emily P. Jones, Nandita S. Mani and Rebecca B. Carlson \\ University Libraries, University of North Carolina at Chapel Hill, \\ Chapel Hill, North Carolina, USA
}

Carolyn G. Welker

School of Information and Library Science, University of North Carolina at Chapel Hill, Chapel Hill, North Carolina, USA, and Michelle Cawley and Fei Yu University Libraries, University of North Carolina at Chapel Hill, Chapel Hill, North Carolina, USA initiatives in LIS literature

Received 2 July 2021 Revised 24 August 2021

3 November 2021

17 November 2021 Accepted 17 November 2021

\begin{abstract}
Purpose - The objective of this study is to establish the current state of library and information science (LIS) scholarship pertaining to anti-racism, equity, inclusion and social justice initiatives.

Design/methodology/approach - Using comprehensive search strategies, three LIS databases were searched for relevant literature published in the last 10 years and results were exported and de-duplicated using Endnote. Citations were screened by two blinded, independent reviewers based on pre-defined eligibility criteria. Citations in the final data set were then hand coded by three reviewers using deductive coding. Subject terms for all citations were categorized and consolidated to identify major themes across the corpus of included publications. Results were analyzed using bibliometrics and thematic analysis.

Findings - A total of 691 unique citations were included in this analysis based on inclusion criteria. Publication productivity has generally increased from 2011 to 2020; findings show publications from 170 source titles and 944 authors representing 33 countries. Prevalent themes included access to information, multiculturalism and social justice. Various populations groups, areas of LIS practice, library types and social justice topics have been addressed in the literature. Over 15\% of citations focused on anti-racism efforts in LIS. Originality/value - This study applied both bibliometric and thematic approaches to analyzing LIS literature at macro and micro levels regarding anti-racism, equity, inclusion and social justice.
\end{abstract}

Keywords Librarianship, Social justice, Anti-racism, Inclusion, Marginalized communities, Multiculturalism Paper type Research paper

\section{Background}

Libraries are perceived by society to be a welcoming, service-oriented space where the public can receive assistance with finding trustworthy information, learn new skills, apply for jobs and gather in a safe space to address challenges facing their communities (Horrigan, 2016).

(C) Emily P. Jones, Nandita S. Mani, Rebecca B. Carlson, Carolyn G. Welker, Michelle Cawley and Fei Yu. Published by Emerald Publishing Limited. This article is published under the Creative Commons Attribution (CCBY 4.0) licence. Anyone may reproduce, distribute, translate and create derivative works of this article (for both commercial and non-commercial purposes), subject to full attribution to the original publication and authors. The full terms of this licence may be seen at http://creativecommons. org/licences/by/4.0/legalcode.

The authors wish to acknowledge Adam Dodd, MIS for his assistance with development of figures in this paper.

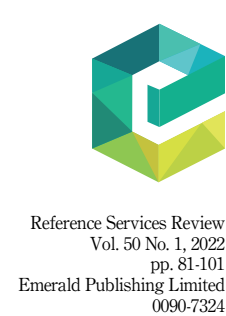

DOI 10.1108/RSR-07-2021-0032 
RSR

50,1

Librarians are perceived to be professionals with specialized expertise in information-seeking and instruction (Fagan et al., 2021). Additionally, libraries have been depicted in the literature as a beacon of diversity and inclusion and librarians as being selfless community servants (Farkas, 2020; Santamaria, 2020). However, some have pushed back against this vocational awe, including Fobazi Ettarh, who argued that the deification of librarians and libraries, "result[s] in the beliefs that libraries as institutions are inherently good and sacred, and therefore beyond critique" (Ettarh, 2018). She asserts that this has created a mythos around libraries that has allowed the institution's roots in and continued support of white supremacy to be overlooked. Building on Ettarh's argument, Meredith Farkas maintains that when an institution is beyond critique, opportunities to make changes for the better remain unnoticed (Farkas, 2020). Libraries and librarianship have benefited from vocational awe; however, the reality is that libraries operate within racist societies, frameworks, systems and histories which undoubtedly have impacted the profession's past and present. Without critical examination and intentional action, the harmful effects of systematic racism, oppression and white supremacy will continue to negatively impact our future.

Although libraries remain embedded within white supremacist structures and the library and information science (LIS) field "struggles to address issues of diversity, inclusion, or social justice in consistent ways" (Gibson et al., 2017) a few libraries and library associations around the world have demonstrated how they have engaged in social justice and human rights issues (Gorham et al., 2016) and moved from passive neutrality toward positive action by advocating against injustice, inequity, racism and inaccessibility (American Library Association, 1997, 2021; Australian Library and Information Association, 2019; Bats, 2016; Dick, 2016; Khoir et al., 2015; Merlo-Vega and Chu, 2015; Mississippi Humanities Council, 2020; Sonnie, 2018; UIC University Library, 2021). On May 25, 2020, George Floyd was murdered by police as an officer knelt on his neck for over eight minutes. Protests against police brutality erupted around the world and many libraries expressed statements against the continued oppression of Black people and shared reading lists meant to help educate the public on anti-racism. This comes after years of protests around the world against instances of injustice, prejudice and inequality. In response, librarians and library associations have issued "calls to action" that implore the field to reimagine what libraries can be and how they can prioritize and advance anti-racism, equity and social justice work (Brown et al., 2018; Cheshire and Stout, 2020; Espinal et al., 2018; Farkas, 2020; Gibson et al., 2020; Hodge and Williams, 2021; Leung and LópezMcKnight, 2020).

Globally, modern social unrest and social justice movements are imploring society to examine how we, on a personal and at an organization level, have and are contributing to continued oppression and marginalization, and to identify ways we can work toward social betterment and equity for all. LIS needs to examine and combat evidence of structural racism and white supremacy within the field in order to truly fulfill its mission of providing information to all. One first step is to identify how, and to what extent, LIS scholarship has been dedicated to reporting and analyzing systems, policies, procedures and structures to mitigate the marginalization of underrepresented communities. In addition, it would be helpful to know how this work has been shared through publications, what topics have been addressed, and how this work has been incorporated in LIS practice.

Sung and Parboteeah completed a content analysis of diversity-related research published between 1995 and 2015 in four, highly impactful, LIS journals and reported an increase of articles over time and found that most studies focused on age, gender and ethnicity related factors (Sung and Parboteeah, 2017). Mongeon et al. (2021) conducted a bibliometric analysis of race-related research in LIS during the last 40 years and noted that while there is an increasing amount of race and racism-focused literature, it still makes up only a small portion of total LIS scholarship and is cited less than other, equivalent LIS 
research. Winberry and Bishop (2021) reviewed social justice research in the LIS literature in the past 20 years and found that despite an increase in the amount of literature available over time, and the wide range of contexts in which the studies appeared, few studies have investigated the research landscape of this area.

Therefore, this study aims to establish the current state of LIS scholarship pertaining to anti-racism, equity, inclusion and social justice and to identify potential opportunities for future engagement by answering the following five research questions (Table 1).

\section{Methods}

Study design

Building on previous examinations of LIS literature on similar topics, we applied systematic search, bibliometric and thematic analysis to LIS literature regarding anti-racism, equity, inclusion and social justice. Two authors (Jones and Carlson) developed comprehensive literature searches to identify relevant literature pertaining to racism, anti-racism or social justice work in LIS literature. The initial search strategy, developed in an iterative manner, was conducted in Library and Information Science Source via EBSCOhost and used a combination of subject headings and text words. Once finalized, searches were translated for and executed in two other LIS databases, Library and Information Science Abstracts (LISA) via ProQuest and Library, Information Science and Technology Abstracts (LISTA) via EBSCOhost. Searches were limited to English language only, publication date (2011-2021), and by publication format (academic journal publications and conference papers and proceedings). All searches were executed on April 21, 2021. Full search strategies can be found in the supplemental appendix.

Citations were exported from individual databases, imported into Endnote and de-duplicated. All unique citations underwent independent, blinded title/abstract screening based on predetermined eligibility criteria (Table 2) by two authors (Jones and Yu) using

1 a. In the last 10 years, how many publications have focused on anti-racism, inclusion, equity and social justice in the LIS field?

b. In which journals are these topics being published?

c. What is the geographic representation of authorship of these publications?

d. What topics emerged from the overall citation set?

2 Which populations have been addressed when examining antiracism, equity or inclusion, and social justice in LIS practice?

3 What social justice topics are most prevalent in the literature?

4 What areas of LIS practice have been reported regarding anti-racism, inclusion, equity and social justice efforts?

5 How have anti-racism efforts been addressed in LIS practice?

Table 1.

Research questions answered in this study

\begin{tabular}{ll}
\hline Inclusion & Exclusion \\
\hline About anti-racism, equity or inclusion or social & $\begin{array}{l}\text { Not about anti-racism, equity or inclusion or social justice } \\
\text { topic }\end{array}$ \\
justice topic & Not specific to LIS field \\
Specific to LIS field & Obituaries, CV, errata, corrigenda, meeting agenda, book \\
Academic journal publications, conference & reviews, conference previews \\
papers and proceedings & No English translation for title and abstract \\
Title and abstract in English language &
\end{tabular}

Table 2.

Inclusion and exclusion criteria used for study selection 
RSR

50,1

\section{4}

Excel $^{\circledR}$ (Microsoft Corporation: Redmond, Washington). Conflicts were resolved by two different authors (Mani and Carlson).

\section{Bibliometric analysis}

Once screening was completed, bibliometric and network analysis were applied to all included citations upon the following measures in each category (Table 3). Metadata were extracted from the exported citation records in CSV format. Due to the size of the corpus and variation in terminology used, an overall topic analysis was conducted using subject terms that were extracted from citation metadata. In addition, based on a thematic analysis codebook developed for this study, subject terms were categorized and consolidated into similar concepts so that prevalent themes could be disclosed. Therefore, results of the subject topic co-occurrence network and heat map do not reflect actual instances of subject terms in citation metadata, but instead show the intensity of thematic subject areas observed through term categorizing and consolidation. Microsoft Excel and VOSviewer (Version 1.6.16) (Van Eck and Waltman, 2021), a free bibliometric analysis tool as well as Tableau (Version 2020.2.2) (Tableau Software, LLC, 2021) were used for data analysis and visualization.

\section{Thematic analysis}

To complement bibliometric analysis which demonstrates a research landscape at the macrolevel, thematic analysis using a deductive coding approach was applied for our research questions around emerging themes at the micro-level so that the context in which anti-racism, equity, inclusion and social justice could be ascertained (research questions 2-5). Citation title and abstracts were reviewed and hand-coded by three authors (Jones, Mani and Carlson) to identify themes across five core areas: population served, anti-racism initiatives (if applicable), social justice topics, area of LIS practice and library type. Two authors (Jones and Mani) established a codebook (Table 4) for hand-coding based on initial examination of titles and abstracts of included citations. When applicable, instances of these five areas were coded each time based on the context of a citation; therefore, codes and citations are not represented in a 1:1 ratio. For example, one citation addressing community outreach to immigrants, refugees and non-native language speakers, would have been counted once for each population category (three in total).

\section{Results}

After literature searches were performed in three LIS databases, a total of 1,732 citations were identified. After de-duplication, 956 unique citations underwent manual screening. In total, 691 citations were identified as being eligible for inclusion in this report. A flow diagram of the study selection process can be found in Figure 1.

\begin{tabular}{|c|c|c|c|c|}
\hline & Category & Metrics & $\begin{array}{l}\text { Citation } \\
\text { metadata }\end{array}$ & Tools \\
\hline \multirow[t]{3}{*}{$\begin{array}{l}\text { Bibliometric } \\
\text { measure }\end{array}$} & Productivity & - Total number of publications per year & Publication year & $\begin{array}{l}\text { Microsoft } \\
\text { Excel }\end{array}$ \\
\hline & Source titles & $\begin{array}{l}\text { - Total number of source titles } \\
\text { - } \quad \text { Top source titles }\end{array}$ & Publishing titles & $\begin{array}{l}\text { Microsoft } \\
\text { Excel }\end{array}$ \\
\hline & Author & $\begin{array}{l}\text { - Total number of unique contributing authors } \\
\text { - } \\
\text { - }\end{array}$ & $\begin{array}{l}\text { Author names } \\
\text { and country } \\
\text { affiliation }\end{array}$ & $\begin{array}{l}\text { Microsoft } \\
\text { Excel } \\
\text { VOSviewer }\end{array}$ \\
\hline $\begin{array}{l}\text { Subject } \\
\text { measure }\end{array}$ & Themes & - Co-occurrence of categorized subject terms & $\begin{array}{l}\text { Categorized } \\
\text { subject terms }\end{array}$ & $\begin{array}{l}\text { Microsoft } \\
\text { Excel } \\
\text { VOSviewer }\end{array}$ \\
\hline
\end{tabular}

Table 3.

Bibliometric and subject area measures 


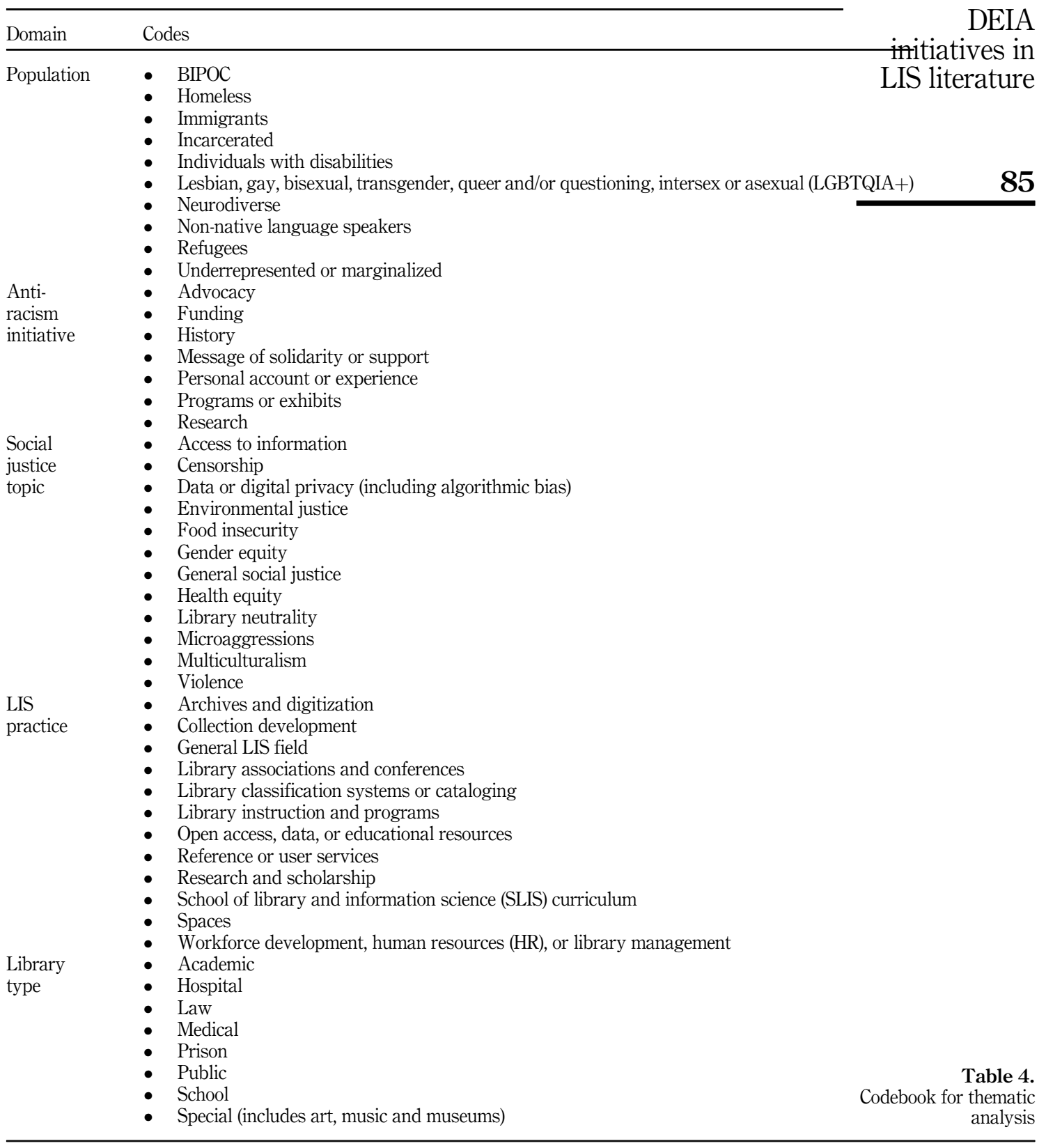

RQ1a. In the last 10 years, how many publications have focused on anti-racism, inclusion or equity and social justice in the LIS field?

From 2011 to 2021 ( $n=691)$, publication productivity increased and peaked in 2020 (Figure 2). Given the literature search was conducted in April 2021, the publication count for 
RSR

50,1

\section{6}

Figure 1.

Flow diagram of

literature search and study selection
Figure 2.

Distribution of included publications by year

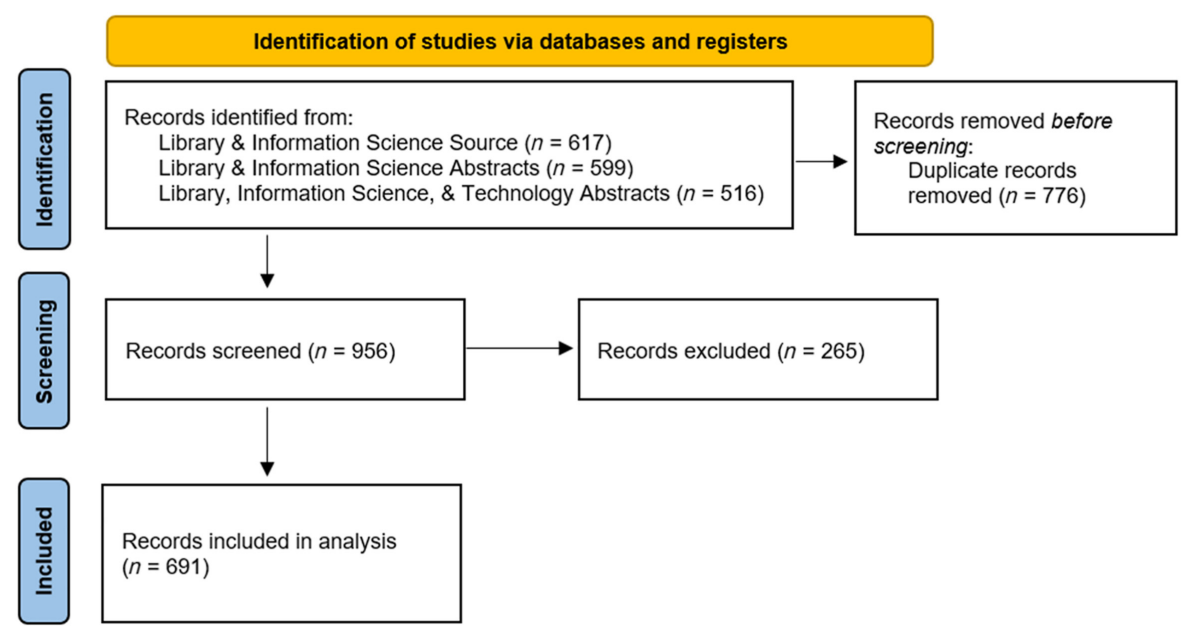

Number of Publications by Year

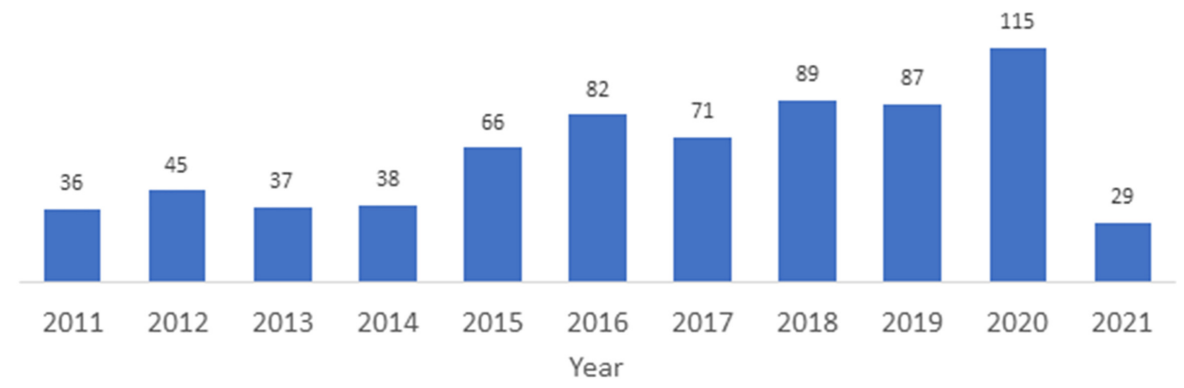

2021 represented partial output for the year. From 2011 to 2020, the average number of publications was 66.2 per year.

$R Q 1 b$. In which journals are these topics being published?

The included citations appeared in 170 sources; Library Trends published most $(n=41)$ and 17 sources published 10 or more publications (Figure 3). Most articles (95\%) were published by LIS sources while 8 articles (5\%) appeared in sources outside of LIS (e.g. Australian Feminist Studies, Journal of the Career Development Group, Journal of Consumer Health on the Internet and First Monday).

$R Q 1 c$. What is the geographic representation of authorship of these publications?

A total of 944 unique authors contributed to the included citations. Among them, 107 authors published two or more articles and four authors published five or more articles (i.e. Paul Jaeger, Bharat Mehra, Vandana Singh and Loriene Roy). Globally, contributing authors are distributed over 33 countries (Figure 4) with publications occurring most from the United States $(n=509)$, Canada $(n=62)$ and Australia $(n=22)$. 


\section{Top Publishing Source Titles}

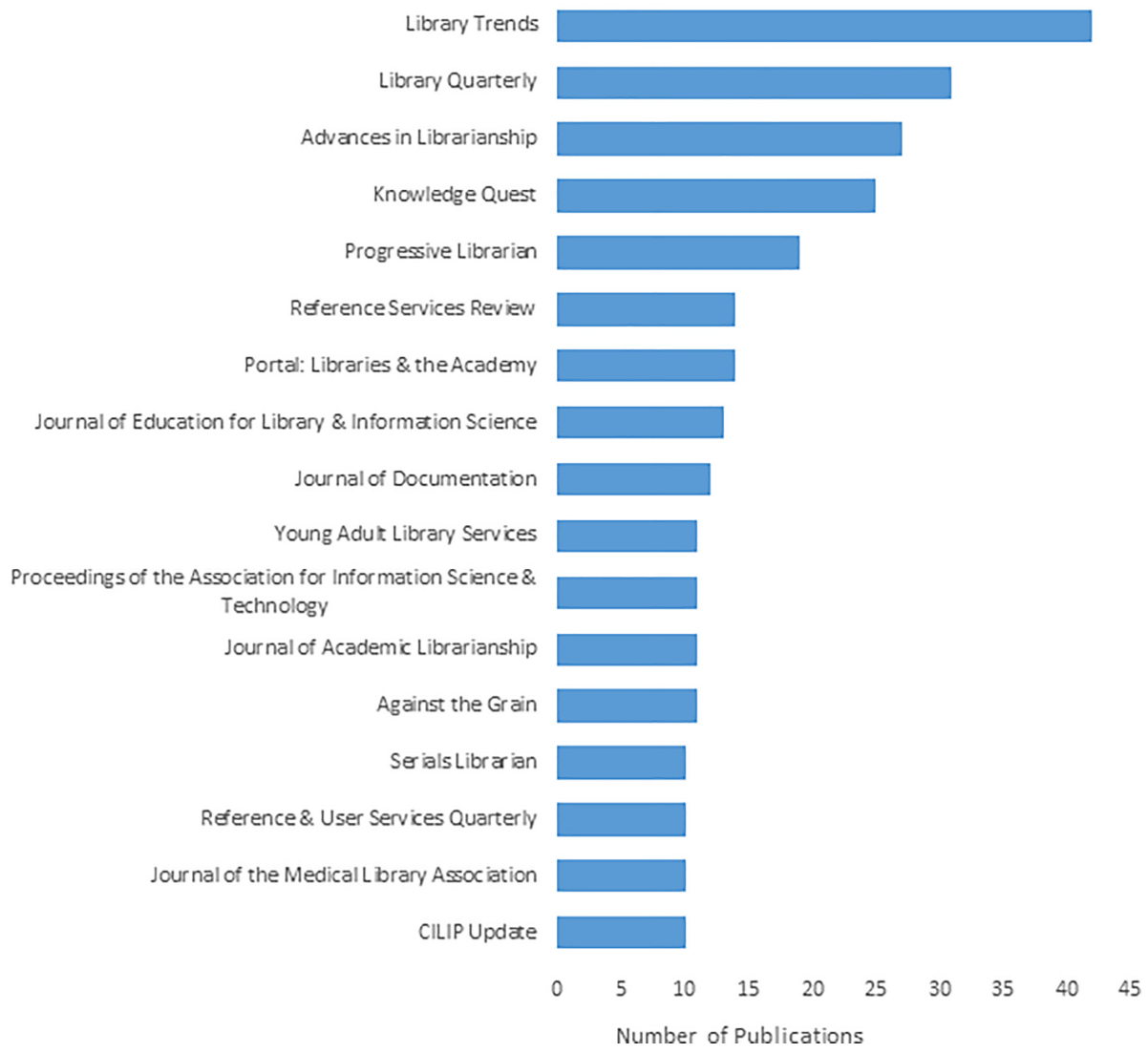

DEIA initiatives in LIS literature

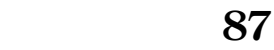

RQ1d. What topics emerged from the overall citation set?

Over 1,800 subject terms were extracted from citation metadata that resulted in 44 handcoded categories representing topics across the entire corpus. Among them, library workforce $(n=213)$, multiculturalism $(n=176)$ and social justice $(n=144)$ were the three major subject areas (Figure 5). In addition, as the subject topic heat map (Figure 6) indicates, other intensively discussed subjects included race and anti-racism $(n=140)$, library services $(n=128)$, library collection $(n=123)$, library instruction and programs $(n=102)$ and library administration and management $(n=95)$.

$R Q 2$. Which populations have been addressed when examining anti-racism, equity or inclusion and social justice in LIS practice?

Through the process of hand coding citation title and abstracts, populations that libraries have served were identified. When citations addressed specific population groups, Black, Indigenous and People of Color (BIPOC) were represented most in the included publications $(n=298)$ followed by mentions of unspecified, underrepresented or marginalized groups $(n=180)$. Lesbian, gay, bisexual, transgender, queer and/or questioning, intersex or asexual 
RSR

50,1

88
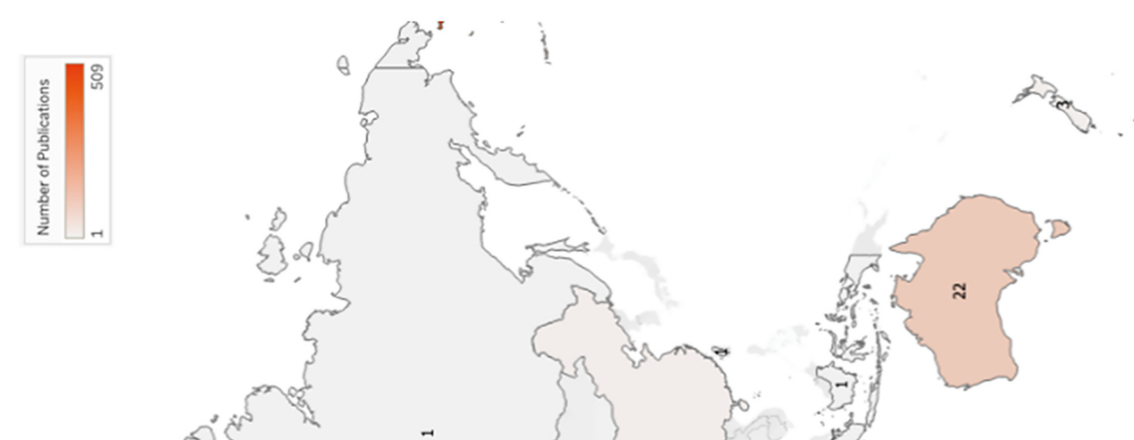

Figure 4.

Geographic

distribution

contributing authors

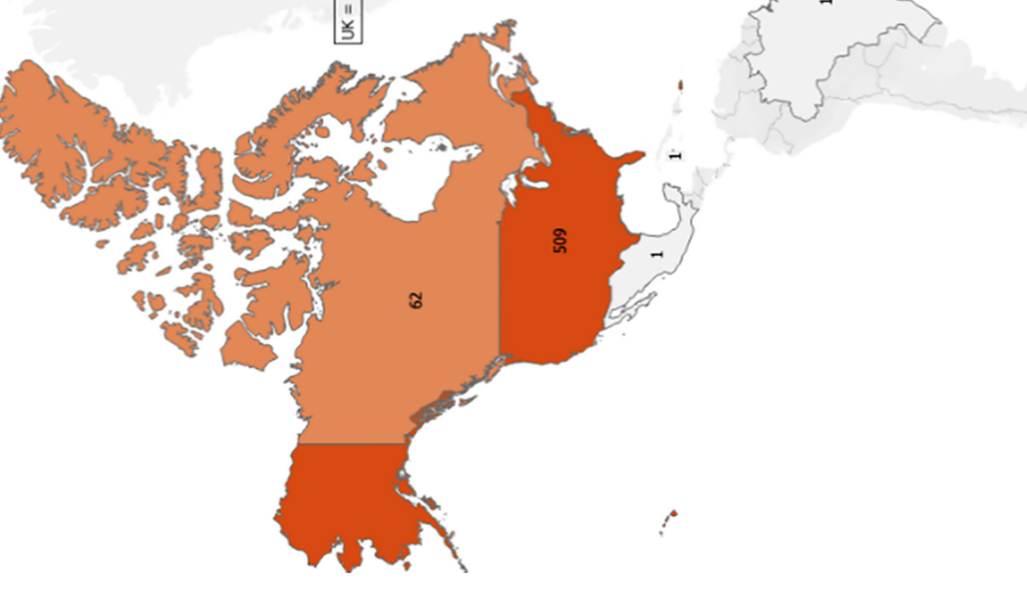




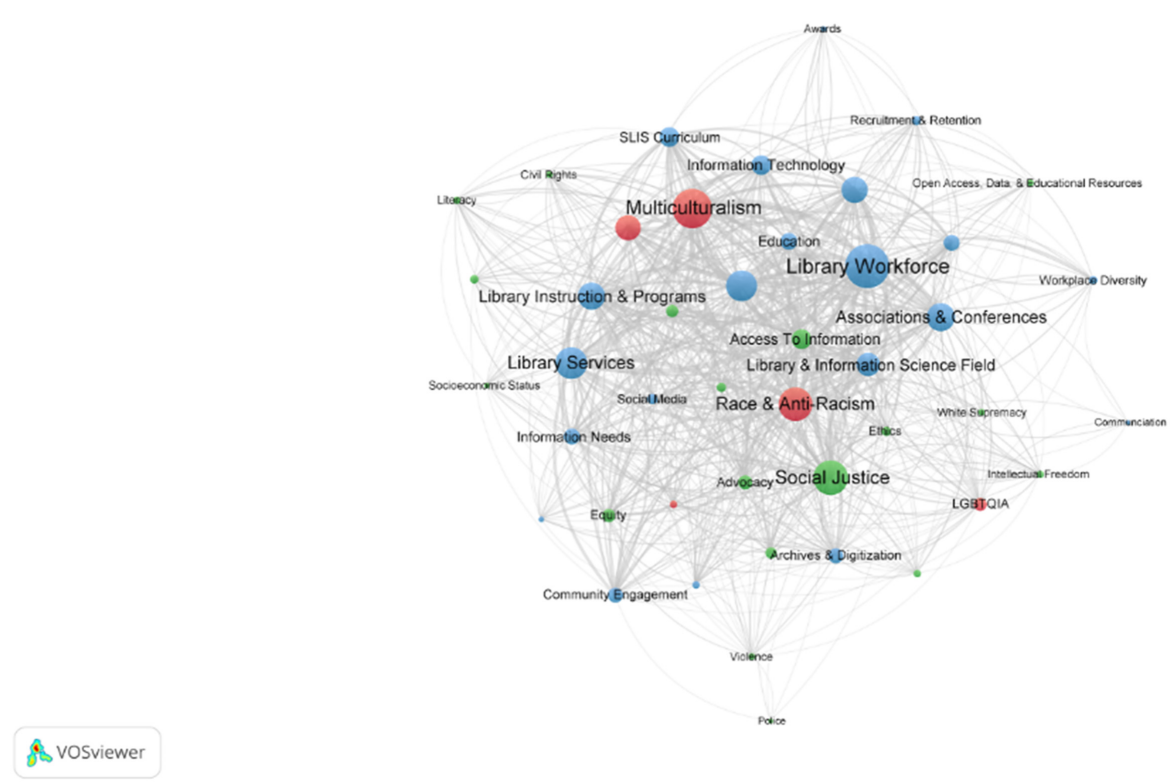

\section{DEIA initiatives in LIS literature}

89

$($ LGBTQIA +$)(n=54)$, refugees and immigrants $(n=52)$, individuals with disabilities $(n=25)$ and non-native language speakers $(n=18)$ were also identified in the literature. Less frequently represented populations were homeless, neurodiverse and incarcerated. Results of the population group distribution represented in the literature are presented in Figure 7.

RQ3. What social justice topics are most prevalent in the literature?

Librarian involvement in social justice work was demonstrated across various topics of the literature. General social justice work not specific to our hand-coded topics occurred most frequently $(n=362)$. Of topics mentioned specifically, hand-coding analysis demonstrated access to information $(n=172)$, multicultural collections and programming $(n=98)$, gender equity $(n=41)$, library neutrality $(n=23)$, health equity $(n=16)$ and data or digital privacy (including algorithmic bias) $(n=16)$. Other topics identified included microaggressions, censorship, violence, environmental justice and food insecurity. A full listing of topics and counts of occurrences from the literature are presented in Figure 8.

RQ4. What areas of LIS practice have been reported regarding anti-racism, inclusion or equity and social justice efforts?

Broadly, LIS engagement in social betterment was seen across various types of libraries (Figure 9a). When library type was specified, academic libraries were observed the most in the literature $(n=154)$, followed by public $(n=120)$ and school libraries $(n=63)$. Other library types including law, medical, hospital, prison, and special libraries were also represented.

Additionally, LIS activism regarding anti-racism, inclusion, equity and social justice spanned virtually all areas of practice. Research and scholarship $(n=175)$, collection development $(n=131)$, library associations $(n=93)$, reference and user services $(n=89)$, curriculum and instruction $(n=89)$ and workforce development, human resources or management $(n=89)$ were the most prevalent in the literature. Other types of LIS practice represented included Schools of Library and Information Science (SLIS), cataloging and 
RSR

50,1

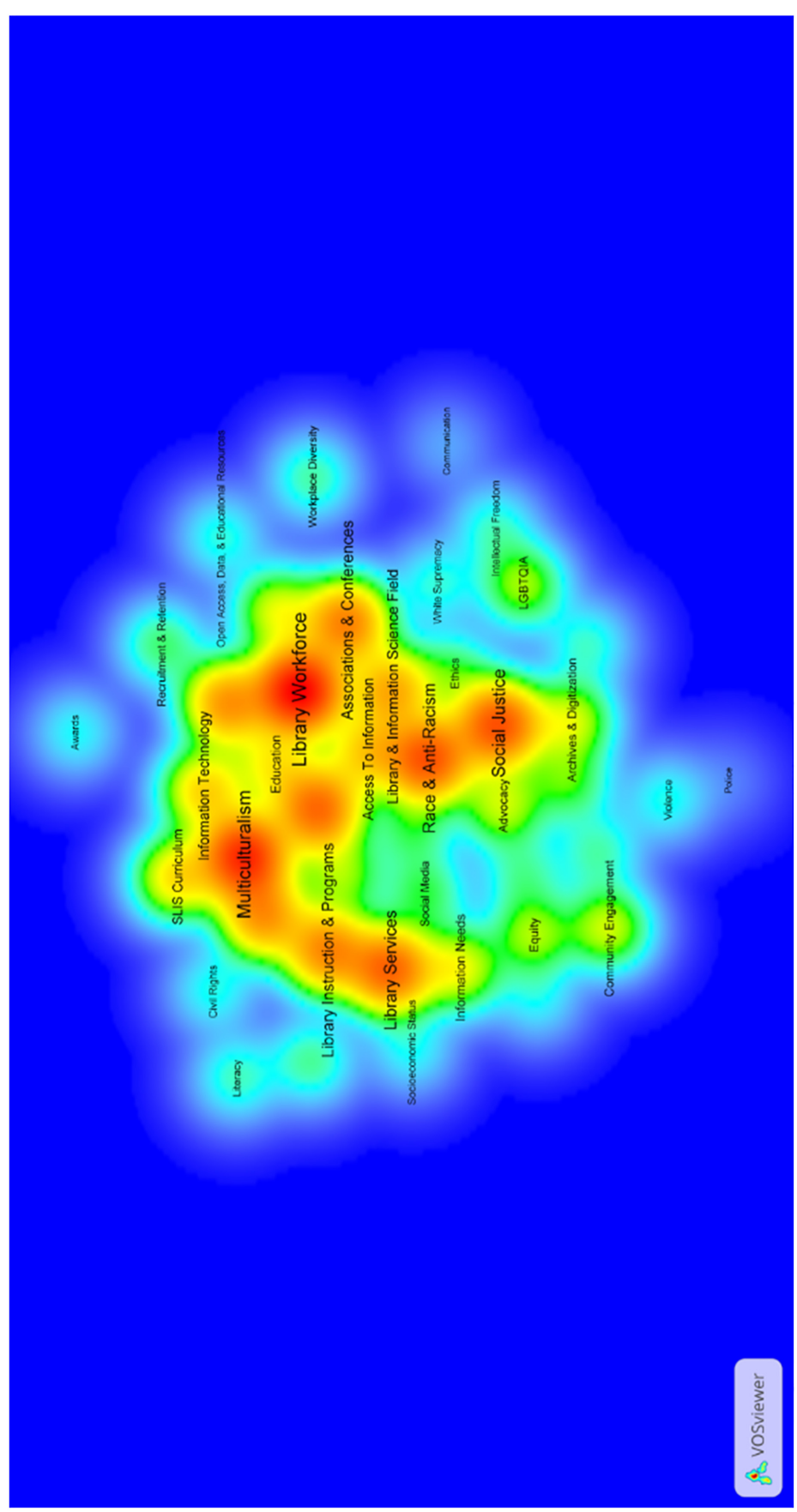

Figure 6.

Subject topic heat map 


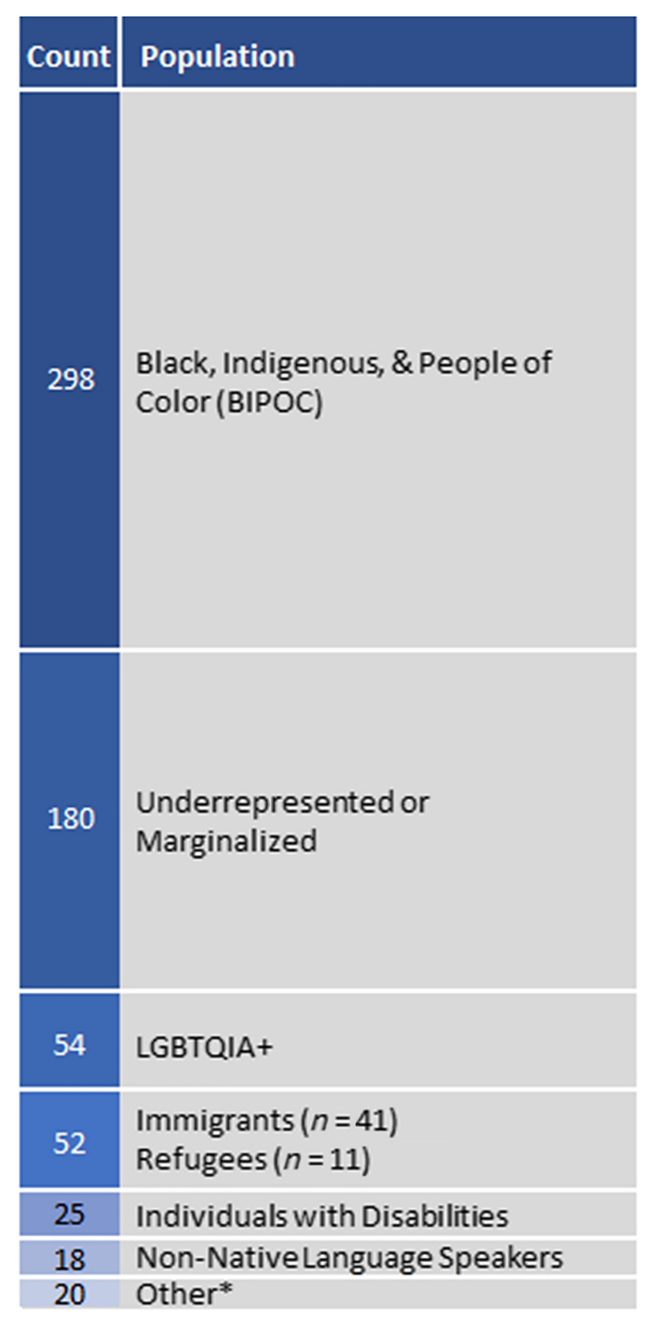

DEIA initiatives in LIS literature

91

Figure 7.

Hand-coded count by population group. *Other category includes individuals experiencing homelessness $(n=7)$; neurodiverse individuals $(n=7)$; incarcerated individuals $(n=6)$

classification systems, archives and digitization and library spaces. A complete list of LIS practices engaged in this work can be found in Figure 9b.

RQ5. How have anti-racism efforts been addressed in LIS practice?

The LIS field has engaged in anti-racism initiatives in a few identifiable ways. A total of 108 $(15.63 \%)$ citations mentioned the word racism, racist, anti-racism or antiracist (including plural and hyphenated versions). Within this subset, anti-racism initiatives identified pertained to broad advocacy or raising awareness $(n=60)$, programming or exhibits $(n=20)$, research $(n=15)$, personal accounts or experiences $(n=10)$, messages of solidarity or support $(n=8)$, commentaries on historical events $(n=6)$ or funding $(n=1)$. Results of antiracism work in LIS, including the specific practices undertaking this work, are presented in Figure 10. 
RSR

50,1

\section{2}

Figure 8.

:Hand-coded count by top social justice topics. *Other category

includes

microaggressions

$(n=14)$; censorship

$(n=11)$; violence

$(n=8)$; environmental

justice $(n=5)$; food insecurity $(n=3)$

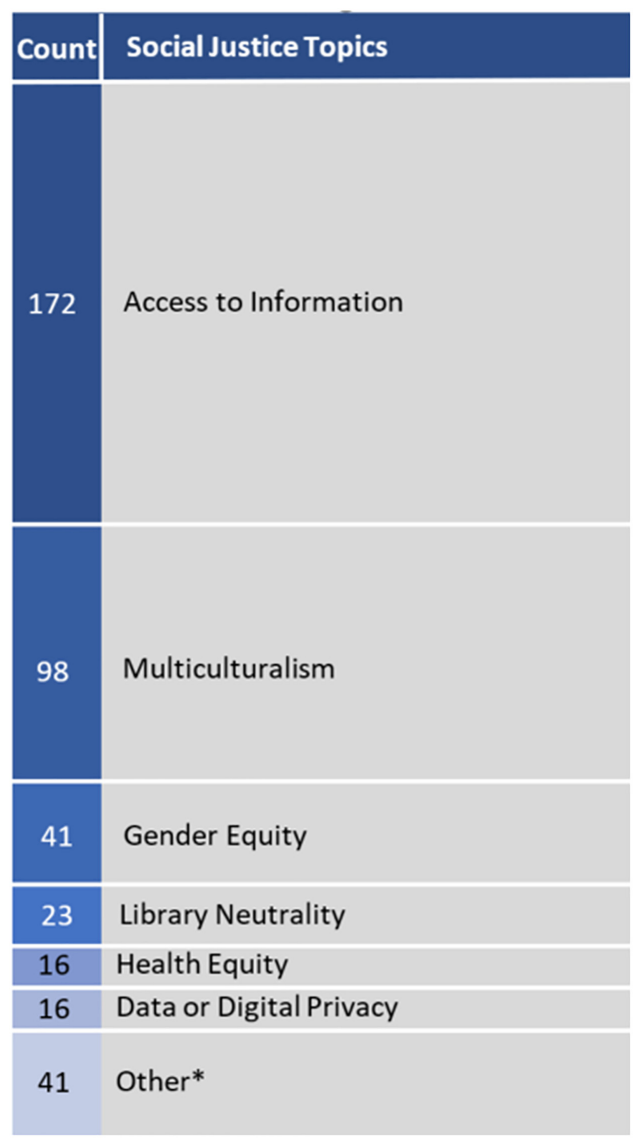

\section{Discussion}

The publication trend disclosed by our results indicates that LIS literature on anti-racism, equity, inclusion and social justice have increased during the past ten years. Despite this increase, publications on these topics make up a small portion of the entire LIS literature and these findings are consistent with observations from previous studies (Mongeon et al., 2021; Sung and Parboteeah, 2017). Social and political movements and unrest motivated libraries, LIS professionals, and researchers to participate in scholarship on these critical areas (Winberry and Bishop, 2021). This type of scholarly work has been promoted and published by sources such as Library Trends, Library Quarterly and Advances in Librarianships, which embrace a variety of perspectives, approaches, trends in professional librarianship and the role of libraries in communities and society (Insight, 2022; Johns Hopkins University Press, 2020; The University of Chicago Press Journals, 2021).

While we found diverse geographic representation in our sample, publication counts skewed heavily toward the United States (US). We were excited to find such breadth in scholarly contributions on anti-racism, equity, inclusion, and social justice in LIS; however, information is lacking on a global level. Specifically, global representation is limited regarding what work has been undertaken, what aspects are critical to address in terms of services, curriculum, spaces and collections, and how needs may differ based on cultural 


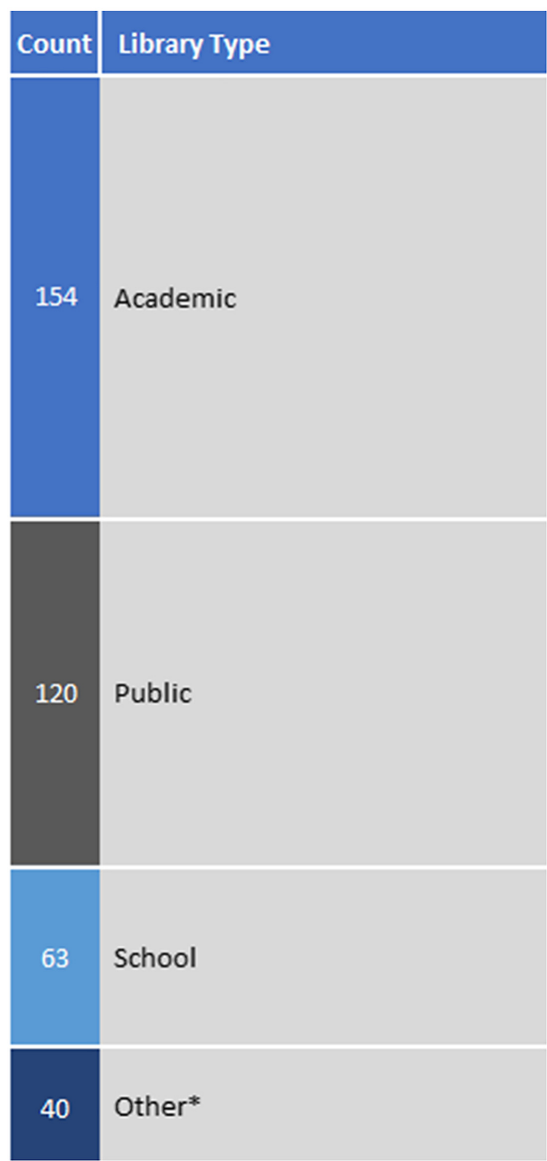

(a)

\begin{tabular}{|c|c|}
\hline Count & US Practice Area \\
\hline 175 & Research \& Scholarship \\
\hline 131 & Collection Development \\
\hline 93 & $\begin{array}{l}\text { Library Associations \& } \\
\text { Conferences }\end{array}$ \\
\hline 89 & Library Instruction \& Programs \\
\hline 89 & $\begin{array}{l}\text { Workforce Development, Human } \\
\text { Resources, Library Management }\end{array}$ \\
\hline 89 & Reference \& User Services \\
\hline 84 & General LIS Field \\
\hline 69 & $\begin{array}{l}\text { School of Library \& Information } \\
\text { Science (SLIS) Curriculum }\end{array}$ \\
\hline 57 & Archives \& Digitization \\
\hline 84 & Other* \\
\hline
\end{tabular}

(b) initiatives in LIS literature

93

Figure 9.

Hand-coded (a) count by library type. *Other category includes law $(n=12)$; medical $(n=12)$; special $(n=10)$; hospital $(n=3)$; prison $(n=3)$. Hand-coded (b) count by LIS practice area. *Other category includes library spaces $(n=33)$; classification systems or cataloging $(n=29)$; open access, data, or educational resources $(n=22)$

context compared to US-focused publications. As publications were analyzed, another aspect that resonated was use of terminology to describe populations served. For instance, utilization of the terms associated with the acronym "BIPOC" may not be as commonly recognized or used globally. Instead, we found many instances of "multicultural" or "multiculturalism" as it related to programs and services aimed towards addressing diversity, equity or inclusion, without specifically naming racial or ethnic groups. Several publications authored by those living in low- and middle-income countries specifically called for activism surrounding open access and educational resources to foster digital inclusivity (Das, 2011; Raju et al., 2020; Uzuegbu and McAlbert, 2012). Creation of more free, open publication venues mitigates barriers and creates opportunities for authors to share their work regardless of where they live or the socioeconomic situation of the libraries in which they are situated.

Our thematic analysis showed that much work has been done to address social justice particularly in areas related to access to information and providing multicultural programs and services (Figure 8). The concept of access to information dealt with how libraries are engaging with communities to identify what type of programming they need and bridging 


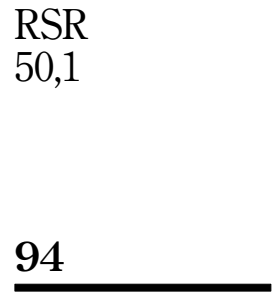

Figure 10.

Hand-coded (a) count by type of anti-racism activity. *Other category includes history $(n=6)$; funding $(n=1)$. Hand-coded (b) count by LIS practice area. *Other category includes archives and digitization $(n=5)$; cataloging or classification systems $(n=5)$; library spaces $(n=5)$; open access, data, or educational resources $(n=2)$

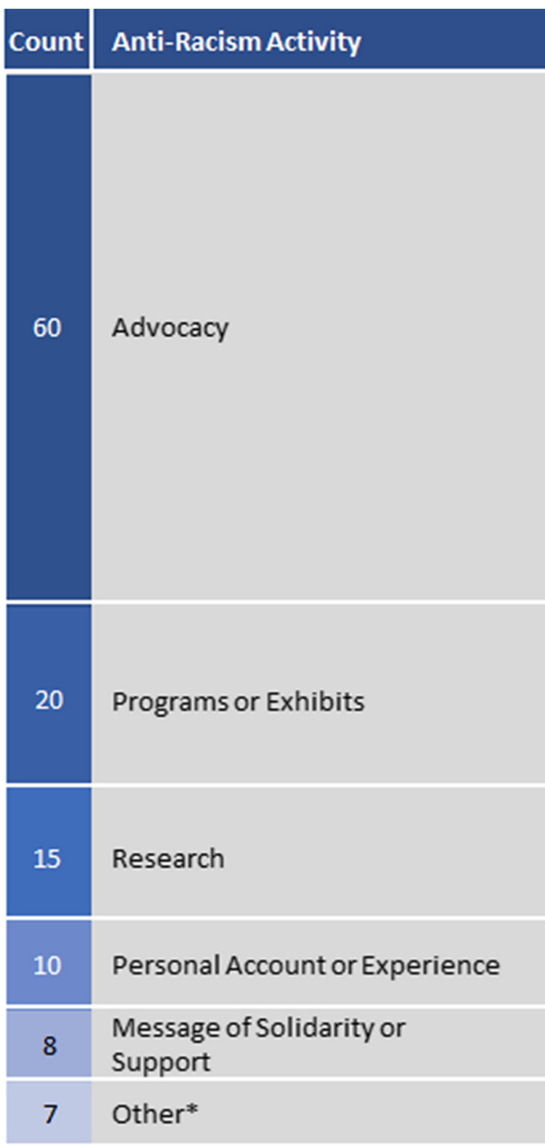

(a)

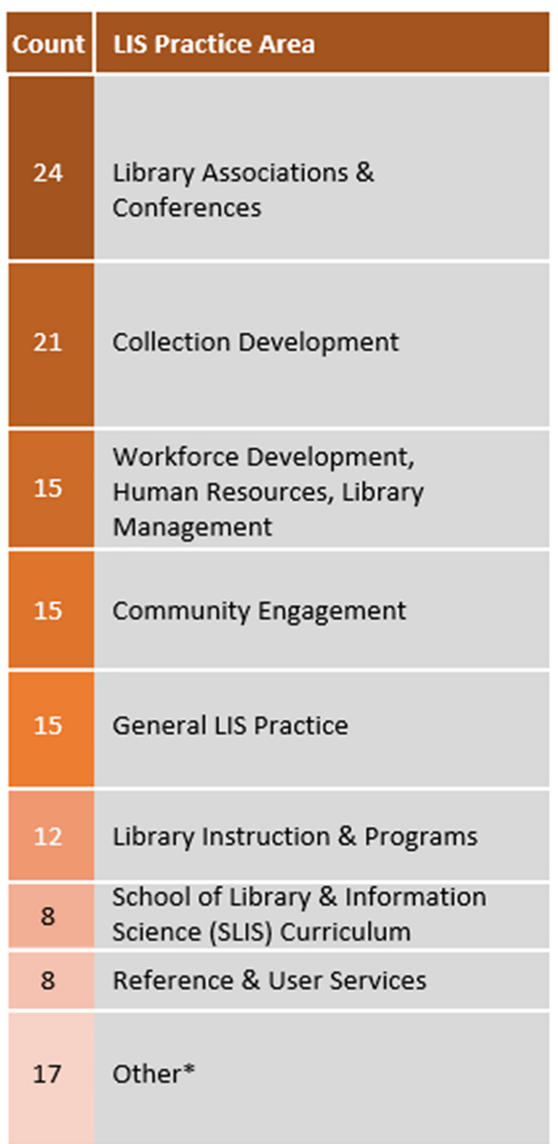

(b)

gaps to meet the information needs of their constituents. The concept of multicultural services and programs dealt with how libraries are keeping specific user populations in mind as they are designing initiatives, creating programs and transforming services. Both of these aspects of social justice mean intentionally engaging with communities and providing essential, targeted library services and there are excellent examples in the literature of how libraries can and are doing this (Fitzgerald, 2011; Kanyengo and Kanyengo, 2011; Meyer, 2017; Michel et al., 2011; Oğuz and Kurbanoğlu, 2013).

Thematic analysis also revealed areas of prominence within LIS practice to be research and scholarship, collection development and library associations and conferences (Figure 9). From a research perspective, many authors have delved into understanding community information needs to improve library services, access to information and provision of collections. In terms of scholarly venues, more conferences and journals should create dedicated space for specialized sections and/or thematic issues related to anti-racism, equity, inclusion, and social justice. For example, a permanent section related to these areas should highlight papers related to LIS practice and perspectives with prioritization given to global and marginalized voices. This would foster a more holistic understanding of how various 
environments and systems are incorporating and attending to anti-racism, equity, inclusion and social justice. We anticipate growth in activities including community engagement to identify user needs beyond those of white voices, analysis and philosophical considerations around collection development, and advocacy and resource support for open access, data and educational resources (Das, 2011; Davis-Castro, 2017; Raju et al., 2020; Salaz et al., 2017; SmithCruz et al., 2014; Uzuegbu and McAlbert, 2012). These areas need to be expanded to ensure equitable access to information and scholarly growth of diverse and global perspectives.

Changes in collection development and classification systems were areas represented in the literature. Practices are moving toward more intentionally including resources and materials beyond those of white voices and spending time understanding community needs. In addition, terminology used in cataloging practices to describe people, populations and culture are being conscientiously examined (Adler and Harper, 2018; Howard and Knowlton, 2018). While archives and digitization have largely focused on making the past accessible, there is a unique opportunity to engage in the documentation, digitization, community engagement, and preservation related to social unrest and injustice currently happening. Many look to libraries for help in identifying trustworthy information; if LIS took an active role in documenting and commentating current affairs, particularly by amplifying the experiences and perspectives of those traditionally minoritized, it could have societal impact on beliefs and attitudes toward racism and the marginalization of underrepresented people.

Library associations are represented often in the literature, either through social justice work at the conference level or through issuing messages of solidarity and support to communities continuing to be harmed by structural racism and white supremacy. Library associations should continue to engage in these conversations about how the field can advance through social betterment while acknowledging the role white supremacy has had within their organization(s). In addition, utilizing conference venues to engage in conversations and share practice-based change is vital for those in the LIS field to understand how their role in antiracism, equity or inclusion and social justice can foster change.

Our bibliometric and thematic analysis revealed that library administration, including recruitment and retention and workforce development was another area of importance within LIS practice. Library administrators are in a unique position to set the strategic course of their library to include prioritization of anti-racism, equity, inclusion and social justice by establishing a call for staff to incorporate activism into their routine job duties. The reckoning initiative at the University of North Carolina at Chapel Hill is an example where library funding has been allocated to support library staff pursuing projects that are geared toward anti-racism work, research and/or projects (University of North, 2021). Support for anti-racist work can also flourish by providing time on task for staff to engage in projects that support library values around issues related to anti-racism and social justice (Binghamton University Libraries, 2021) as well as building antiracist and socially just collections and resources (Boston Public Library Fund, 2020; The Indianapolis Public Library, 2021; University of Wisconsin-Madison Libraries, 2021). Cultivating an organization that upholds these values requires close attention to one's workforce; especially as it relates to recruitment and retention. The latter of which was an emerging area found through thematic analysis and is gaining momentum in terms of its importance as it relates to cultural competency, training needed to support an inclusive culture (e.g. training related to the concept and presence of micro-aggressions) and critical librarianship (Barnett and Witenstein, 2020; Barr-Walker and Sharifi, 2019; Blackburn, 2020; Daniel, 2013; Gosselin and Goodsett, 2019; Lazzaro et al., 2014; Leung and López-McKnight, 2020; Sanchez-Rodriguez, 2021; Zhang and Roy, 2011). How administrators and managers engage future prospects and current staff in libraries necessitates an examination of how job postings and interview questions are crafted, how onboarding is integrated, provision of mentoring and community engagement and how training and professional development are offered to support individuals and groups. initiatives in LIS literature

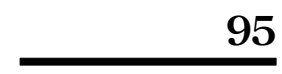


RSR

50,1

\section{6}

When setting strategic priorities, administrators should ensure they invest in staff, provide time and engage in conversation to be able to carry out initiatives that encapsulate anti-racism, equity, inclusion and social justice values. Based on the literature and our experience, we suggest engaging the workforce by using the following strategies:

(1) Allocating funding and time for professional and personal development opportunities for employees (including training).

(2) Establishing taskforces or working groups to address policies and procedures (e.g. security presence in library spaces).

(3) Initiating a library curriculum committee to continuously examine and evaluate library based instructional programming using an anti-racist and inclusive lens.

(4) Identifying research questions that need to be investigated (e.g. to what extent are research from BIPOC authors represented in collections).

(5) Engaging communities to identify library services and programs that meet the needs of diverse populations, especially BIPOC and underserved/marginalized groups.

(6) Partnering with library associations to consider how programs, sponsorships, membership and committee participation can be re-envisioned to promote antiracism, equity, inclusion and social justice values.

(7) Examining and creating guidance and policies around which portraits are placed on walls of prominence, how buildings and spaces are named and exhibits to display.

(8) Providing resources to support digitization of special collections.

(9) Establishing book clubs and discussion groups to advance social discourse.

An interesting finding of this study is that while more than $15 \%$ of publications were about racism in some capacity, eight publications were identified as a message of solidarity or support which mostly came from library organizations, subchapters or LIS journals. While expressions of support and solidarity can be helpful and are generally well-meaning, stopping here, without further critical examination of racist histories and legacies, can do more harm than good. Bharat Mehra (2021) writes that the "performative" nature of these messages often go without acknowledgment or further examination of institutional racism and passivity toward it within the field (or organization). Mehra does not call for messages of solidarity to halt, but simply that they are presented factually along with LIS's history of and role in racialization (Mehra, 2021). Within the publications addressing racism, only one citation was identified that used allocated funding to support programming or services that promoted antiracist action (Kim, 2019). After hundreds of years of prioritizing white voices and interests in collections and programming decisions, it is only natural that library funding be specifically devoted to expanding and facilitating work toward closing the equity gap and dismantling racist systems and structures. Dedicating library funding to support internal grants and/or awards that enable staff to collaborate on projects can foster innovation and create the space for people to move through the continuum of ideation to implementation, which is critical if library systems and structures are to change (American Library Association, 2020; First Peoples Cultural, 2020; National Library of Australia, 2021; University of British Columbia Library, 2021; University of Wisconsin-Madison Libraries, 2021).

This study builds on past examinations of LIS literature published on topics related to diversity, equity, inclusion, accessibility and racism. For this study, research questions and analyses are similar in some respects to previous studies (Mongeon et al., 2021; Sung and Parboteeah, 2017; Winberry and Bishop, 2021), but provide new information about the 
current status of LIS literature. Unlike Sung and Parboteeah (2017), this study was not limited to a subset of high impact journals and included journals across three LIS databases to be more broadly inclusive. Prior studies noted an overall lack of exploration of the existing research in this area and the continued need for future research to examine the growing number of papers published on diversity, equity, inclusion, accessibility and anti-racism in LIS. This study is unique in that it provides a bibliometric and thematic analysis of the current literature to more fully demonstrate dimensionality and gaps in the literature and provides current data from which other researchers could build.

There are several strengths and limitations to this study. One strength can be found in our methodology; to mitigate bias, we followed systematic review methods to retrieve and screen citations. Another strength of this study pertains to the use of hand-coding for the entire subset of citations included in the study. Using a deductive approach, each citation underwent handcoding to assess the qualitative context of the record better. One limitation of this study is that filters (i.e. language, date and publication type) were applied to the comprehensive search strategies. However, these limits were not imposed without careful consideration. To conduct bibliometric analysis, it was necessary for citations to be in the same language; therefore, English was selected due to the authors' familiarity. Publication date and type limits were chosen to focus on the current state of LIS scholarship regarding practice and research. The authors acknowledge that using these limits, in addition to using citation information for this analysis, may have excluded other voices or examples of initiatives not represented in the published literature. Additionally, using language filters and limiting our search to LIS databases may have impacted results of this study regarding global authorship representation. Last, analyses performed in this report were limited to citation data fields including title, abstract and subject terms. Full-text articles were not analyzed; therefore, results are limited to the author's interpretations of the limited information provided in citation data.

More research is needed to investigate in what ways BIPOC and underrepresented or marginalized groups have been served via changes in library services, programs, and/or practices. Furthermore, libraries that have modified policies, procedures, programs, services, budget and collection development philosophies using anti-racism, equity, inclusion or social justice lens are all areas where further investigation is needed.

\section{Conclusion}

This study conducted a systematic survey of LIS literature regarding anti-racism, equity, inclusion and social justice work. In addition to providing a research landscape over the past decade, this current snapshot specifically highlights the populations and social justice topics represented, areas of LIS practice and library types engaged in these activities. While there are good examples of anti-racist and social justice initiatives revealed in the LIS literature, continued investigation and examples of work being integrated in LIS practice are needed. These activities need to be publicly reported, published and shared openly, and should include and prioritize global perspectives along with the voices of the underrepresented and marginalized. With dedication and coordination from libraries and library schools, museums and archives, LIS scholarly venues, and LIS associations, we can advance anti-racism, equity, inclusion and social justice in the field of LIS and for the diverse communities of whom we serve.

\section{References}

Adler, M. and Harper, L.M. (2018), "Race and ethnicity in classification systems: teaching knowledge organization from a social justice perspective”, Library Trends, Vol. 67 No. 1, pp. 52-73, doi: 10. 1353/lib.2018.0025.

initiatives in initiatives in LIS literature 
RSR

50,1

American Library Association (1997), Resolution on IFLA, Human Rights and Freedom of Expression, available at: https://www.ala.org/aboutala/offices/iro/awardsactivities/resolutionifla (accessed 30 June 2021).

American Library Association (2020), Libraries Transform Communities Engagement Grant Guidelines, available at: https:/www.ala.org/tools/programming/LTCEG/guidelines (accessed 30 June 2021).

American Library Association (2021), ALA Executive Board Supports APALA in Recognizing and Condemning Ongoing Anti-Asian Hate Crimes, available at: https://www.ala.org/news/pressreleases/2021/03/ala-executive-board-supports-apala-recognizing-and-condemning-ongoing-anti (accessed 30 June 2021).

Australian Library and Information Association (2019), "Improving library services for Aboriginal and Torres Strait Islander peoples", available at: https://www.alia.org.au/sites/default/files/ Indigenous $\% 20$ collections $\% 20$ and $\% 20$ services $\% 202019 \% 20$ report_FINAL.pdf (accessed 30 June 2021).

Barnett, R.M. and Witenstein, M.A. (2020), "Imagining a climate of equity through a critical theory of love: using CPAR to identify guiding principles that humanize library work", The Journal of Academic Librarianship, Vol. 46 No. 5, p. 102176, doi: 10.1016/j.acalib.2020.102176.

Barr-Walker, J. and Sharifi, C. (2019), "Critical librarianship in health sciences libraries: an introduction”, Journal of the Medical Library Association, Vol. 107 No. 2, pp. 258-264, doi: 10. 5195/jmla.2019.620.

Bats, R. (2016), "Libraries after Charlie: from neutrality to action”, Library Trends, Vol. 65 No. 2, pp. 128-142, doi: 10.1353/lib.2016.0026.

Binghamton University Libraries (2021), Anti-Racism Research and Resource Guide, available at: https://libraryguides.binghamton.edu/antiracism (accessed 29 June 2021).

Blackburn, F. (2020), "Cultural competence: toward a more robust conceptualisation", Public Library Quarterly, Vol. 39 No. 3, pp. 229-245, doi: 10.1080/01616846.2019.1636750.

Boston Public Library Fund (2020), Expansion of Antiracist Reading Lending Collection, available at: https://bplfund.org/antiracist-reading-collection/ (accessed 30 June 2021).

Brown, J., Ferretti, J.A., Leung, S. and Méndez-Brady, M. (2018), “We here: speaking our truth”, Library Trends, Vol. 67 No. 1, pp. 163-181, doi: 10.1353/lib.2018.0031.

Cheshire, K. and Stout, J. (2020), "The moral arc of the library: what are our duties and limitations after 45?”, References Services Review, Vol. 48 No. 2, pp. 219-225, doi: 10.1108/RSR-10-2019-0074.

Daniel, D. (2013), "Gender, race, and age of librarians and users have an impact on the perceived approachability of librarians", Evidence Based Library and Information Practice, Vol. 8 No. 3, p. 73, doi: 10.18438/B8JP5H.

Das, A.K. (2011), "Emergence of open educational resources (OER) in India and its impact on lifelong learning", Library Hi Tech News, Vol. 28 No. 5, pp. 10-15, doi: 10.1108/07419051111163848.

Davis-Castro, C. (2017), "Bridging the knowledge gaps: what grey literature does for the library of congress' Indigenous law portal”, Grey Journal (TGJ), Vol. 13 No. 2, pp. 91-100.

Dick, A.L. (2016), "Librarians and crises in the 'old' and 'new' South Africa”, IFLA Journal, Vol. 42 No. 2, pp. 102-108, doi: 10.1177/0340035216635669.

Emerald Insight, (2022), “Advances in librarianship”, available at: https://www.emerald.com/insight/ publication/issn/0065-2830 (accessed 1 July 2021).

Espinal, I., Sutherland, T. and Roh, C. (2018), "A holistic approach for inclusive librarianship: decentering whiteness in our profession”, Library Trends, Vol. 67 No. 1, pp. 147-162, doi: 10. 1353/lib.2018.0030.

Ettarh, F. (2018), "Vocational awe and librarianship: the lies we tell ourselves", in The Library with the Lead Pipe, available at: https://www.inthelibrarywiththeleadpipe.org/2018/vocational-awe/ (accessed 11 June 2021). 
Fagan, J.C., Ostermiller, H., Price, E. and Sapp, L. (2021), "Librarian, faculty, and student perceptions of academic librarians: study introduction and literature review", New Review of Academic Librarianship, Vol. 27 No. 1, pp. 38-75, doi: 10.1080/13614533.2019. 1691026.

Farkas, M. (2020), "Not beyond critique: the need for critical conversations about our libraries and profession", American Libraries, available at: https:/americanlibrariesmagazine.org/2020/09/01/ not-beyond-critique/, p. 51910.

First Peoples Cultural Council (2020), Digitization Grant Initiative, available at: https://fpcc.ca/ programs_and_grants/digitization-grant-initiative/ (accessed 30 June 2021).

Fitzgerald, B. (2011), "My language: state and territory public libraries collaborating for a multicultural Australia in the digital age", APLIS, Vol. 24 No. 3, pp. 111-115.

Gibson, A.N., Chancellor, R.L., Cooke, N.A., Dahlen, S.P., Patin, B. and Shorish, Y.L. (2020), "Struggling to breathe: COVID-19, protest and the LIS response", Equality, Diversity, and Inclusion, Vol. 40 No. 1, pp. 74-82, doi: 10.1108/EDI-07-2020-0178.

Gibson, A.N., Chancellor, R.L., Cooke, N.A., Park Dahlen, S., Lee, S.A. and Shorish, Y.L. (2017), "Libraries on the frontlines: neutrality and social justice", Equality, Diversity and Inclusion, Vol. 36 No. 8, pp. 751-766, doi: 10.1108/EDI-11-2016-0100.

Gorham, U., Taylor, N.G. and Jaeger, P.T. (2016), "Perspectives on libraries as institutions of human rights and social justice", in Gorham, U., Taylor, N.G. and Jaejer, P.T. (Eds), Advances in Librarianship, Emerald Group Publishing, Bingley, Vol. 41, pp. 1-456.

Gosselin, A. and Goodsett, M. (2019), "Increasing faculty-librarian collaboration through critical librarianship", Collaborative Librarianship, Vol. 11 No. 2, pp. 100-109.

Hodge, T. and Williams, J. (2021), Call to Action, available at: https://americanlibrariesmagazine.org/ 2021/01/04/call-to-action/ (accessed 30 June 2021).

Horrigan, J.B. (2016), Americans' Attitudes toward Public Libraries, Pew Research Center, available at: https://www.pewresearch.org/internet/2016/09/09/americans-attitudes-toward-public-libraries/ (accessed 26 June 2021).

Howard, S.A. and Knowlton, S.A. (2018), "Browsing through bias: the library of congress classification and subject headings for African American studies and LGBTQIA studies", Library Trends, Vol. 67 No. 1, pp. 74-88, doi: 10.1353/lib.2018.0026.

Johns Hopkins University Press (2020), "Library trends", available at: https://www.press.jhu.edu/ journals/library-trends (accessed 1 July 2021).

Kanyengo, B.K. and Kanyengo, C.W. (2011), "Information provision in emergency settings: the experience of refugee communities in Zambia”, Behavioral and Social Sciences Librarian, Vol. 30 No. 4, pp. 246-258, doi: 10.1080/01639269.2011.622256.

Khoir, S., Du, J.T. and Koronios, A. (2015), "Linking everyday information behaviour and Asian immigrant settlement processes: towards a conceptual framework", Australian Academic and Research Libraries, Vol. 46 No. 2, pp. 86-100, doi: 10.1080/00048623.2015. 1024303.

Kim, B. (2019), "Moving forward with LITA”, Information Technology and Libraries, Vol. 38 No. 2, pp. 2-4, doi: 10.6017/ital.v38i2.11093.

Lazzaro, A.E., Mills, S., Garrard, T., Ferguson, E., Watson, M. and Ellenwood, D. (2014), "Cultural competency on campus: applying ACRL's diversity standards", College and Research Libraries News, Vol. 75 No. 6, pp. 332-335.

Leung, S. and López-McKnight, J. (2020), "Dreaming revolutionary futures: critical race's centrality to ending white supremacy", Communications in Information Literacy, Vol. 14 No. 1, pp. 12-26, doi: 10.15760/comminfolit.2020.14.1.2.

Mehra, B. (2021), "Enough crocodile tears! Libraries moving beyond performative antiracist politics", The Library Quarterly, Vol. 91 No. 2, pp. 137-149, doi: 10.1086/713046. 
RSR

50,1

Merlo-Vega, J.A. and Chu, C.M. (2015), "Out of necessity comes unbridled imagination for survival: contributive justice in Spanish libraries during economic crisis", Library Trends, Vol. 64 No. 2, pp. 299-328, doi: 10.1353/lib.2015.0051.

Meyer, N. (2017), "Selecting diverse resources of Native American perspective for the curriculum center: children's literature, leveled readers, and social studies curriculum", Education Libraries, Vol. 34 No. 1, p. 23.

Michel, T.A., Sabino, E., Stevenson, A.J., Weiss, E., Carpenter, A. and Rapkin, B. (2011), "Queens library healthlink: fighting health disparities through community engagement”, Urban Library Journal, Vol. 17 No. 1, doi: 10.31641/ulj170103.

Mississippi Humanities Council (2020), MHC Announces \$29,000 in Anti-Racism Reading Shelf Grants for Public Libraries, available at: http://mshumanities.org/mhc-announces-29000-anti-racismreading-shelf-grants-public-libraries/ (accessed 30 June 2021).

Mongeon, P., Brown, A., Dhaliwal, R., Hill, J. and Matthews, A. (2021), "A bibliometric analysis of racerelated research in LIS”, Education for Information, Vol. 37 No. 1, pp. 1-16, doi: 10.3233/EFI211513.

National Library of Australia (2021), "Fellowships, scholarships and grants", available at: https:// www.nla.gov.au/content/fellowships-scholarships-and-grants (accessed 30 June 2021).

Oğuz, E.S. and Kurbanoğlu, S. (2013), "Strengthening social inclusion in multicultural societies through information literacy”, Information World/Bilgi Dünyası, Vol. 14 No. 2, pp. 270-290, doi: 10.15612/bd.2013.121.

Raju, R., Claassen, J., Pietersen, J. and Abrahamse, D. (2020), “An authentic flip subscription model for Africa: library as publisher service”, Library Management, Vol. 41 Nos 6/7, pp. 369-381, doi: 10. 1108/LM-03-2020-0054.

Salaz, A.M., Johnston, N. and Pickles, C. (2017), "Faculty members who teach online: a phenomenographic typology of open access experiences", The Journal of Academic Librarianship, Vol. 44 No. 1, pp. 125-132, doi: 10.1016/j.acalib.2017.09.006.

Sanchez-Rodriguez, N.A. (2021), "In pursuit of diversity in the CUNY library profession: an effective approach to leadership in academic libraries", Journal of Library Administration, Vol. 61 No. 2, pp. 185-206, doi: 10.1080/01930826.2020.1853470.

Santamaria, M.R. (2020), "Concealing white supremacy through fantasies of the library: economies of affect at work", Library Trends, Vol. 68 No. 3, pp. 431-449, doi: 10.1353/lib.2020.0000.

Smith-Cruz, S., Thistlethwaite, P. and Daniels, J. (2014), "Open scholarship for open education: building the JustPublics@365 POOC”, Journal of Library Innovation, Vol. 5 No. 2, pp. 15-28.

Sonnie, A. (2018), "Advancing racial equity in public libraries: case studies from the field (issue brief)", in Goodwin, G., Nelson, J., Ervin, S., Eastwood, J., Rchardson, T. and Lawton, S. (Eds), Government Alliance on Race and Equity.

Sung, H.-Y. and Parboteeah, P. (2017), "Diversity-related research reported in high-impact library and information science journal literature: a content analysis", Library and Information Science Research, Vol. 39 No. 2, pp. 77-84, doi: 10.1016/j.lisr.2017.03.002.

Tableau Software, LLC (2021), Tableau Desktop Professional Edition, Computer Software, available at: https://www.tableau.com/ (accessed 26 June 2021).

The Indianapolis Public Library (2021), Indy Library Adds over 3,600 Antiracism Books and Movies via Lilly Endowment Grant, available at: https://www.indypl.org/news-and-announcements/ indy-library-adds-over-3600-antiracism-books-and-movies-via-lilly-endowment-grant (accessed 30 June 2021).

The University of Chicago Press Journals (2021), “About the Journal”, available at: https://www. journals.uchicago.edu/journals/lq/about (accessed 1 July 2021).

UIC University Library (2021), UIC University Library Statement against Asian Hate, available at: https://library.uic.edu/about/news/article/10741/uic-university-library-statement-against-asianhate (accessed 30 June 2021). 
University of British Columbia Library (2021), "Funding - indigitization: tools for digitizing and sustaining indigenous knowledge", available at: https://www.indigitization.ca/funding/ (accessed 30 June 2021).

University of North Carolina at Chapel Hill University Libraries (2021), "The reckoning initiative at the university libraries", available at: https:/library.unc.edu/reckoning/ (accessed 29 June 2021).

University of Wisconsin-Madison Libraries (2021), Humanities Education for Anti-Racism Literacy (HEAL) Project Receives a \$5 Million Dollar Grant from the Mellon Foundation's Just Futures Initiative, available at: https://www.library.wisc.edu/news/2021/05/04/humanities-education-foranti-racism-literacy-heal-project-receives-a-5-million-dollar-grant-from-the-mellon-foundationsjust-futures-initiative/ (accessed 30 June 2021).

Uzuegbu, C.P. and McAlbert, F.U. (2012), "Digital librarians and the challenges of open access to knowledge: the Michael Okpara University of Agriculture (MOUAU) library experience", Library Philosophy and Practice, available at: https:/digitalcommons.unl.edu/libphilprac/740/.

Van Eck, N.J. and Waltman, L. (2021), VOSviewer, Computer Software, available at: https://www. vosviewer.com/ (accessed 29 June 2021).

Winberry, J. and Bishop, B.W. (2021), "Documenting social justice in library and information science research: a literature review", Journal of Documentation, Vol. 77 No. 3, pp. 743-754, doi: 10.1108/ JD-08-2020-0136.

Zhang, S.L. and Roy, L. (2011), "Recruiting future librarians from diverse backgrounds: model projects in the United States", Journal of Library and Information Science (Taipei), Vol. 37 No. 1, pp. $73-80$.

\section{Appendix}

Supplementary materials are available in online for this article.

\section{Corresponding author}

Emily P. Jones can be contacted at: epjones3@email.unc.edu

For instructions on how to order reprints of this article, please visit our website: 